\section{DNA Restriction Fragment Length Variability in Diospyros kaki and Related Diospyros Species}

\author{
Yuri Nakamura and Shozo Kobayashi \\ Akitsu Branch, Fruit Tree Research Station, Akitsu Hiroshima 729-24, Japan
}

Additional index words. RFLPs, Japanese persimmon, mtDNA, cpDNA

\begin{abstract}
Restriction fragment length analyses of mitochondrial DNA (mtDNA) and chloroplast DNA (cpDNA) were carried out on 11 cultivars of Japanese persimmon (Diospyros kaki Thunb.) and five other Diospyros species. Total genomic DNA was digested with seven restriction endonucleases, Southern blotted, and hybridized with five mtDNA probes (PstI or SalI fragments of Brassica campestris L. mtDNA) and one cpDNA probe [pTBal, BamHI fragment of Nicotiana tabacum (L.) cpDNA]. All Japanese persimmon cultivars displayed identical mtDNA and cpDNA fragment patterns, while polymorphisms among species were observed using both mtDNA and cpDNA probes. A low degree of polymorphism was observed between $D$. kaki, D. oleifera Cheng., D. kuroiwai Nakai, $D$. virginiana $\mathbf{L}$., and $D$. lotus $\mathrm{L}$., suggesting that these species are closely related. A high degree of polymorphism was observed between $D$. rhombifolia Hemsl. and the other five species, indicating that this species is more distantly related to the other five.
\end{abstract}

Restriction fragment length polymorphisms (RFLPs) have been used as genetic markers to identify species and cultivars, evaluate genetic diversity, and map genes of interest in numerous crops (Hubbard et al., 1992; Mauro et al., 1992; Menancio et al., 1990; Song et al., 1990; Watillon et al., 1991; Yamamoto et al., 199 1). cpDNA and mtDNA are generally inherited maternally (Conde et al., 1979; Ichikawa and Hirai, 1983; Vedel et al., 1981). cpDNA and mtDNA RFLPs provide useful markers for studying phylogenetic and evolutionary relationships and for breeding studies (Baldwin et al., 1991; Haghighi and Hancock, 1992; Ishikawa et al., 1992). Japanese persimmon, native to East Asia, is one of the most important fruit-beating trees in Japan. This species has been cultivated for hundreds of years, and there are more than 1000 cultivars. However, nothing is known about the degree of heterogeneity of mtDNA and cpDNA among $D$. kaki cultivars. We analyzed mtDNA and cpDNA in D. kaki and its closely related Diospyros species to evaluate cytoplasmic diversity among the cultivars of $D . k a k i$ and to provide new information on phylogenetic relationships of $D$. kaki and its closely related Diospyros species.

Received for publication 16 Dec. 1992. Accepted for publication 25 Nov. 1993. Contribution no. E164 of the Fruit Tree Research Station. We thank M. Sugiura and J.D. Palmer for their generosity in providing cpDNA or mtDNA clones. Thanks are also extended to M. Yamada for his valuable advice and suggestions and M.J. Clarkin for reading the manuscript. The cost of publishing this paper was defrayed in part by the payment of page charges. Under postal regulations, this paper therefore must be hereby marked advertisernent solely to indicate this fact.

\section{Materials and Methods}

Total DNA was isolated from fully expanded fresh leaves of 11 typical cultivars of D. kaki and five of its related Diospyros species (Table 1). The trees were grown in the experimental orchard of the Akitsu Branch, Fruit Tree Research Station, Japan, according to the method of Honda and Hirai(1990) with the following modification: leaves were frozen in liquid $\mathrm{N}_{2}$ and ground into powder that then was suspended in extraction buffer [ 100 mm Tris- $\mathrm{HCl}$ (pH 8.0), $50 \mathrm{~mm}$ EDTA, $500 \mathrm{~mm}$ $\mathrm{NaCl}, 20 \mathrm{mg}$ polyvinylpyrolidone (PVP)/ml, $100 \mathrm{~mm}$ 2-mercaptoethanol] and pelleted by centrifugation $(35,000 \times \mathrm{g}$ for $5 \mathrm{~min}$ at $4 \mathrm{C})$ twice before DNA extraction. DNA $(1 \mu \mathrm{g})$ was digested with one of seven restriction endonucleases (BamHI, DraI, EcoRI, HindIII, PstI, PvuII, XbaI; Nippon Gene Corp., Japan), and the resulting fragments were separated by electrophoresis through $0.8 \%$ agarose gels at a constant $0.8 \mathrm{~V} / \mathrm{cm}$ for 13 to $14 \mathrm{~h}$. After electrophoresis, the DNA was transferred to Tropilon 45 nylon membrane (Tropix Corp.) as described by Southern (1975). The DNA was bound with a UV crosslinker (Spectronics Corp.). DNA fragments used as probes were prepared from plasmid pTBa1, which con- tains a 19.6-kb BamHI fragment of Nicotiana tabacum cpDNA (Sugiura et al., 1986), or were PstI or SalI fragments of Brassica campestris mtDNA plasmids P4.8, P9.7, P5.7, P12.4, and S11.8 (Palmer and Shields, 1984). Probe DNA was' labeled with digoxigenin (DIG) using a DIG labeling kit (Boennger Mannheim). Membranes were prehybridized for $4 \mathrm{~h}$ at $68 \mathrm{C}$ in a hybridization buffer [ $5 \mathrm{x}$ $\mathrm{SSC}(0.15 \mathrm{~m} \mathrm{NaCl}, 0.015 \mathrm{~m}$ trisodium citrate, $\mathrm{pH}$ 7.0), $5 \mathrm{mg}$ blocking reagent $/ \mathrm{ml}$ (Boehringer Mannheim Cat. no. 1096176), $1 \mathrm{mg} \mathrm{N}$ lauroylsarcosine- $\mathrm{Na} / \mathrm{ml}, \quad 0.2 \mathrm{mg}$ sodium dodecyl sulfate $(\mathrm{SDS}) / \mathrm{ml}$, then hybridized overnight at $68 \mathrm{C}$ in the same buffer containing the labeled probe. The hybridized membrane was washed twice with $2 \times \mathrm{SSC}, 1 \mathrm{mg} \mathrm{SDS} / \mathrm{ml}$ for $5 \mathrm{~min}$ at room temperature, followed by two washes of $0.5 \times \mathrm{SSC}, 1 \mathrm{mg} \mathrm{SDS} / \mathrm{ml}$ for 15 min at $65 \mathrm{C}$. Probe-target DNA hybrids were visualized by chemiluminescent detection of DIG-labeled nucleic acids (Boehringer Mannheim). Genetic similarities were estimated based on the number of shared fragments between paired samples.

\section{Results and Discussion}

when blots of restriction-endonucleasedigested genomic DNA were hybridized with five mtDNA probes, RFLPs among species were observed in 32 out of 35 probe-enzyme combinations. However, mtDNA restriction patterns within species of D. kaki were monomorphic, regardless of the restriction endonucleases and mtDNA probes used. Polymorphisms were detected among species. For example, the P9.7 mtDNA probe did not detect polymorphisms in BamHI- digested DNA of D. kaki, D. oleifera, D. kuroiwai, and D. lotus. However, RFLPs were detected among $D$. virginiana, D. rhombifolia, and these four species (data not shown). When the S11.8 mtDNA probe was hybridized to HindHIdigested DNA, D. oleifera, D. kuroiwai, D. virginiana, and $D$. lotus revealed a $17.5-\mathrm{kb}$ fragment not present in $D$. kaki, and $D$. rhombifolia displayed instead a unique 14.5$\mathrm{kb}$ fragment (Fig. 1A). The P5.7 mtDNA probe hybridized to BamHI- digested DNA revealed a polymorphism unique to D. kuroiwai (Fig. 1B). By combining the mtDNA RFLP data, we were able to distinguish all species. When the frequencies of shared fragments between paired species (F value) were calculated, $D$. kaki, D. oleifera, D. kuroiwai, D. virginiana,
Table 1. Diospyros species examined for mtDNA and cpDNA polymorphisms.

\begin{tabular}{lll}
\hline \hline Species & \multicolumn{1}{c}{ Cultivar } & Origin \\
\hline D. kaki $^{2}$ & Shi-shan-shi, Da-mo-pan, Luo-tian-tian-shi & China \\
& Ban-si, Chong-do-si & Korea \\
& Fuyuu, Gosho, Jisha, Saijou & Japan \\
D. oleofera & Tai-wan-zheng-shi, Tai-wan-hong-shi & Taiwan \\
D. kuroiwai & & China \\
D. virginiana & & Japan \\
D. lotus & & USA \\
D. rhombifolia & & Japan \\
Elan & & China \\
\hline
\end{tabular}

${ }^{2}$ Eleven typical cultivars of $D$. kaki, distantly related to each other, were selected for analysis.

"Diospyros lotus is widely distributed in East, Central, and West Asia (Ng, 1979). The clones of D. lotus analyzed in this study originated in Japan. 
and D. lotus showed high relatedness to each other, with $\mathrm{F}$ values among them generally $>0.9$. In contrast, D. rhombriforia showed lower relatedness with the other species, illustrated by $\mathrm{F}$ values $\approx 0.6$.

Similar results were obtained when digests were probed with the pTBal cpDNA probe. Intraspecific variation of $D$. kaki was not detected. RFLPs were detected among species, except D. kaki and D. oleifera, when EcoRI-, DraI-, HindIII-, and XbaI- digested DNA blots were hybridized with pTBa1. When pTBal was hybridized to DraI-digested DNA, the 11 cultivars of D. kaki, D. oleifera, and D. kuroiwai were monomorphic. RFLPs were observed among $D$. virginiana, D. lotus, D. rhombriforia, and the three other Diospyros species (Fig. 2). $F$ values obtained by comparing frequency of shared fragments' relative degree of relatedness were similar to those detected from mtDNA RFLPs,

Diospyros kaki cultivars show high variation in morphological and physiological characteristics and have been distinguished by isozyme markers (Tao and Sugiura, 1987; Tao et al., 1989). When the mtDNA and cpDNA probes were used to detect RFLPs, however, intraspecific variation was not detected. These data suggest that the mtDNA and cpDNA of D. kaki are highly homogeneous. Diospyros kaki, D. oleifera, D. kuroiwai, D. virginiana, and $D$. lotus showed high relatedness to each other; in contrast, D. rhombriforia showed lower relatedness with the other species. This result agrees well with morphological taxonomy. $\mathrm{Ng}$ (1978) hypothesized that D. kaki originated from D. roxburghii. If his hypothesis is true, then the mtDNA and cpDNA fragment patterns of $D$. roxburghii should be the same as or more similar to D. kaki than to other closely related species. However, we were unable to obtain a sample ofD. roxburghii for analysis. Additional RFLP analysis with more species, especially with $D$. roxburghii, is neccesary to clarify the phylogenetic relationships among $D$. kaki and its closely related Diospyros species.

\section{Literature Cited}

Baldwin, B.G., D.W. Kyhos, J. Dvorak, and G.D. Carr. 1991.. Chloroplast DNA evidence for a North American origin of the Hawaiian silversword alliance (Asteraceae). Proc. Natl. Acad. Sci. USA 88:1840-1843.

Conde, M. F., D.R. Pring, and C.S. Levings, III. 1979. Maternal inheritance of organelle DNA's in Zea mays-Zea perennis reciprocal crosses. J. Hered. 70:24

Haghighi, K. and J.F. Hancock. 1992. DNA restriction fragment length variability in genomes of highbush blueberry. HortScience 27:44-47.

Honda, H. and A. Hirai. 1990. A simple and efficient method for identification of hybrids using nonradioactive rDNA as probe. Jpn. J. Breeding 40:339-348.

Hubbard, M., J. Kelly, S. Rajapakse, A. Abbott, and R. Ballard. 1992. Restriction fragment length polymorphisms in rose and their use for cultivar identification. HortScience 27:172-173.

Ichikawa, H. and A. Hirai. 1983. Search for the female parent in the genesis of Brassica napus by chloroplast DNA restriction patterns. Jpn. J. Genet. 58:419-424.

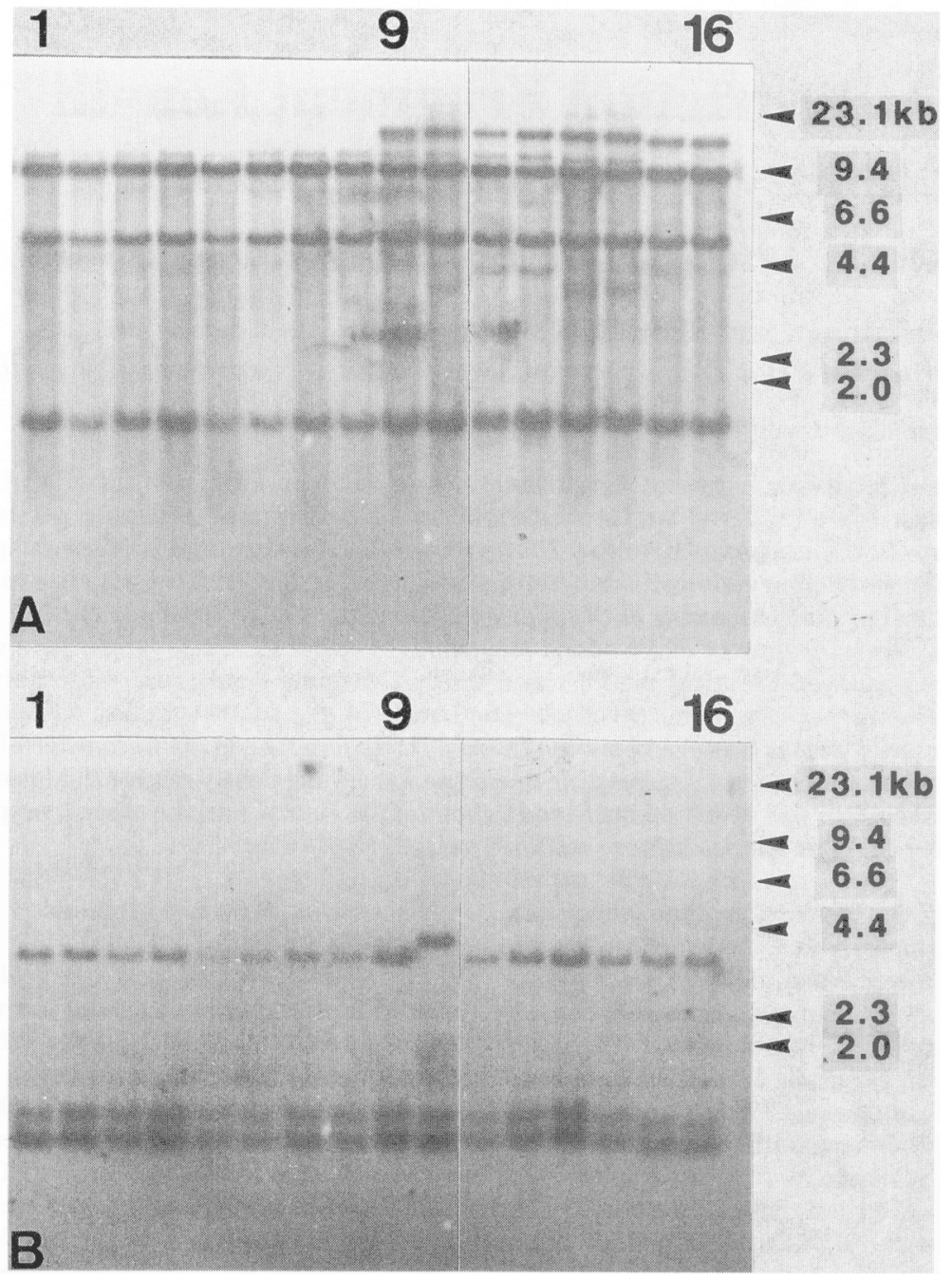

Fig. 1. RFLPs of Diospyros species: (A) when mtDNA probe S11.8 was hybridized to HindIII-digested DNA, (B) when mtDNA probe P5.7 was hybridized to BamHI- digested DNA. Lanes 1-8, D. kaki; lane 9, D. oleifera; lane 10, D. kuroiwai; lanes 11-12, D. virginiana; lanes 13-14, D. lotus; lanes 15-16, D. rhombrifolia.

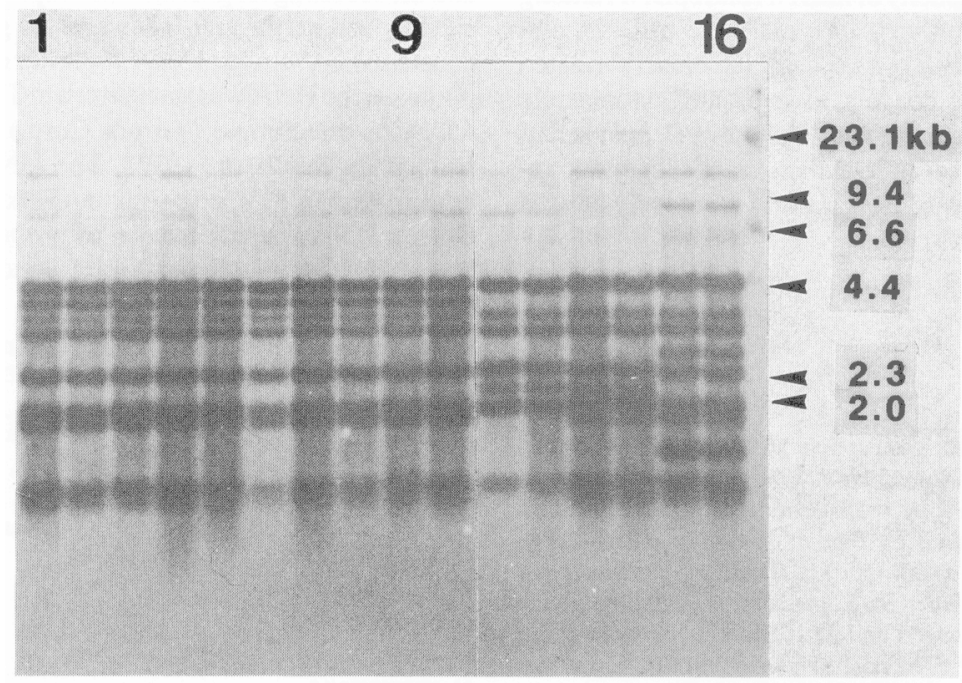

Fig. 2. RFLPs of Diospyros species when the cpDNA probe pTBa1 was hybridized to DraI- digested DNA. Lanes 1-8, D. kaki; lane 9, D. oleifera; lane 10, D. karoiwai lanes 11-12,D. virginiana; lanes 13-14, D. lotus; lanes 15-16, D. rhombrifolia. 
Ishikawa, S., S. Kate, S. Imakawa, T. Mikami, and Y. Shimamoto, 1992. Organelle DNA polymorphism in apple cultivars and rootstock. Theor. Appl. Genet. 83:963-967.

Mauro, M.C., M. Strefeler, N.F. Weeden, and B.I. Reisch. 1992. Genetic analysis of restriction fragment length polymorphisms in Vitis. J. Hered. $83: 18-21$,

Menancio, D.I., A.G. Hepburn, and T. Hymowitz. 1990. Restriction fragment length polymorphisms (RFLP) of wild perennial relatives of soybean. Theor. Appl. Genet. 79:235-240.

Ng, E.S.P. 1978. Diospyros roxburghii and the origin of Diospyros kaki. Malaysian Forester 41:4350.

Ng, E.S.P. 1979, The origin of Diospyros lotus and other notes on the genus Diospyros (Ebenaceae). Malaysian Forester 42: 165-170,

Palmer, J.D. and C.R. Shields. 1984. Tripartite struc- ture of the Brassica campestris mitochondrial genome. Nature 307:437-440.

Song, K., T.C. Osbom, and P.H. Williams. 1990. Brassica taxonomy based on nuclear restriction fragment length polymorphisms (RFLPs). Theor. Appl. Genet. 79:497-506,

Southern, E.M. 1975. Detection of specific sequence among DNA fragments separated by gel electrophoresis. J. Mol. Biol. 98:503-517.

Sugiura, M., K. Shinozaki, N. Zaita, M. Kosuda, and M. Kumano. 1986. Clone bank of the tobacco (Nicotiana tabacum) chloroplast genome as a set of overlapping restriction endonuclease fragments: Mapping of eleven ribosomal protein genes. Plant Sci. 44:211-216.

Tao, R. and A. Sugiura. 1987. Cultivar identification of Japanese persimmon by leaf isozymes. HortScience 22:932-935.

Tao, R., T. Tetsumura, and A. Sugiura. 1989, Use of leaf isozymes to discriminate among Japanese persimmon (Diospyros kaki L.) cultivars. Memoirs College Agr. Kyoto Univ. 135:3142.

Vedel, F., F. Quetier, Y, Cauderon, F. Dosba, and G. Doussinault. 1981. Studies on maternal inheritance in polyploid wheats with cytoplasmic DNAs as genetic markers. Theor. Appl. Genet. 59:239245.

Watillon, B., P. Druart, P.D. Jardin, R. Kettmann, P. Boxus, and A. Burny. 1991. Use of random cDNA probes to detect restriction fragment length polymorphisms among apple clones. Scientia Hort. 46:235-243,

Yamamoto, N., G. Ono, K. Takashima, and A. Totsuka. 1991. Restriction fragment length polymorphisms of grapevine DNA with phenylalanine ammonia-lyase cDNA. Jpn. J. Breeding 41:365-368. 